\title{
Pescommancs Public Health Bulletin
}

\section{HEPATITIS C: THE INVISIBLE VIRUS PRODUCING VERY VISIBLE PROBLEMS}

John M Dwyer, Professor of Medicine, University of New South Wales and Clinical Director, Prince of Wales / Prince Henry Hospitals

$\mathbf{P}$ enetration of the hepatitis $\mathrm{C}$ virus (HCV) into the Australian community has generated a major public health problem. Estimates of Australians infected with hepatitis $\mathrm{C}$ range from 50,000 to 100,000 . As this virus may take from 10 to 25 years to produce cirrhosis and liver cancer, even if we stop its spread completely we may still expect to see 600 cases of cirrhosis presenting for the first time each year for the next 20 years.

Recently, there has been publicity in the NSW media that up to one in every 250 Australians is a carrier of the HCV.

How did so many people become infected? HCV is spread by blood-toblood contact. In the Australian community the highest prevalence of hepatitis $\mathrm{C}$ seropositivity appears to be in the injecting drug user (IDU) population and people who received a blood transfusion before the introduction of screening of blood for hepatitis $\mathrm{C}$ antibodies in February 1990.

A recent study in Victoria showed that among those individuals who regularly inject drugs, or did so at some stage of their life, 68 per cent have hepatitis $\mathrm{C}$ antibodies ${ }^{1}$. The potential for spread of this virus by sharing of injecting equipment is obvious. Recent data estimate that 80,000 current and former IDUs have antibodies to hepatitis C.

Therefore, we can expect 8,000 to 10,000 new hepatitis C infections annually among IDUs based on this research.

Sexual transmission and transmission in the household setting appears to be less common. Mother to baby transmission (vertical transmission) can occur ${ }^{2}$. In studies relying on abnormal liver function tests and the presence of antibodies to HCV in serum, it appears that the transmission rate is less than 5 per cent. Recent studies using a polymerase chain reaction to detect HCV-RNA have revealed a vertical transmission rate close to 33 per cent.

Most people have subclinical illness in the initial stages of hepatitis C infection; acute hepatitis and jaundice are less common.

Long-term sequelae include chronic active hepatitis, cirrhosis and liver cancer. The HCV is toxic to liver cells (hepatocytes). Liver function tests may be mildly abnormal (increase in serum ALT levels) and people may suffer chronic ill-health. Fifty per cent of people with HCV are believed to progress to chronic infection. Symptoms are often vague; excessive fatigue, mild abdominal discomfort and intermittent nausea.

\section{Contents}

\section{Articles}

97 Hepatitis C: the invisible virus producing very visible problems

99 Public communication in the management of an outbreak of infectious disease

100 Epidemic astbma surveillance in the New England Region 1990-1992

Public bealth abstracts

\section{Infectious diseases}

\section{Notifications}

107 Public bealth response to a suspected case of Lassa fever

\section{Correspondence}

Please address all correspondence and potential contributions to.

The Editor;

NSW Public Health Bulletin, Public Health Division, NSW Health Department Locked Bag No 961 , North Sydney NSW 2059 Telephone: (02) 3919218 Facsimile: (02) 3919232 


\section{Hepatitis C: The invisible virus}

- Continued from page 97

Public health strategies include:

- education of the community;

- testing of those at risk of infection; and

needle and syringe exchange programs.

Blood product recipients (including renal dialysis patients) and organ recipients before February 1990, male homosexuals and sex industry workers may be tested for hepatitis C. Medical practitioners should consider hepatitis $\mathrm{C}$ in the differential diagnosis of abnormal liver function.

People infected with the hepatitis $\mathrm{C}$ virus should:

- not donate blood or organs;

- not share needles or syringes;

not share personal articles such as

toothbrushes, razors, or combs;

- advise health care workers, including

doctors and dentists, that they are

hepatitis $\mathrm{C}$ positive;

$\square$
$\square$
$\square$ clean up blood spills using household bleach; cover cuts or wounds with a dressing; safely dispose of blood-stained tissues, sanitary napkins and other dressings; and reduce their alcohol intake.

Interferons are anti-viral agents that are normal products of the healthy immune system. Research is continuing into the use of alpha interferon in the management of chronic hepatitis $\mathrm{C}$. The drug is expensive - a six-month course of interferon costs about $\$ 3,000$. The community cost for the management of a patient with end-stage liver disease is at least $\$ 100,000$. Therefore, the cost of managing one patient with end-stage liver disease is approximately equivalent to the cost of treating 33 patients with interferon ${ }^{3}$.

1. Crofts N, Hopper JL, Bowden DS, Breschkin AM, Milner R, Locarnini SA. Hepatitis C virus infection among a cohort of Victorian injecting drug users. Med J Aust 1993; 159:237-241.

2. Kuroki T, Nishiguchi S, Fukuda K et al. Vertical transmission of hepatitis C (HCV) detected by HCV-RNA analysis. GUT 1922; 34:S52S53.

3. Farrell GC. Interferon treatment for chronic viral hepatitis in

Australia; is it worth it? Med J Aust 1992; 156:873-876.

\section{EDITORIAL COMMENTS}

This article highlights the state of knowledge of hepatitis C in Australia.

Current tests do not distinguish between incident and prevalent cases, and the long-term sequelae of HCV infection in Australia are still unclear.

While more than 60 per cent of Australians who are hepatitis $\mathrm{C}$ positive are injecting drug users or received a blood transfusion before February 1990, there remains a large group of people with unidentified risk factors for hepatitis C.
Interferon has been approved for marketing but has not been approved for listing on the Pharmaceutical Benefits Scheme.

Public health actions are undertaken by NSW Health and other agencies such as NUAA (NSW Users and AIDS Association), ACON (AIDS Council of NSW), CEIDA (Centre for Education and Information about Drugs and Alcohol), SWOP (Sex Workers Outreach Program) and Family Planning Association.

These actions include:

- screening of blood, tissue and organ donors since February 1990; needle/syringe exchange programs, drug counselling and treatment (such as methadone) and outreach programs; Skin Penetration Guidelines for tattooists and acupuncturists;

education programs and access to bleach in prisons; adoption of universal precautions in the health care setting;

- promotion of safer sex, particularly condom use;

- information sheet for the general public;

- hepatitis C surveillance through notification system and identification of risk factors of acute cases; and

a plan for management of hepatitis B and C in NSW in each administrative area.

The evidence on the cost-effectiveness of interferon for the treatment of hepatitis $\mathrm{C}$ is ambiguous. Costeffectiveness is not an "absolute concept" and it is only appropriate to compare the alternative use of resources. Conclusions about the cost-effectiveness are only as valid as the epidemiological and natural history data available. In the case of hepatitis $\mathrm{C}$ there is still uncertainty about the epidemiological and natural history. In addition, the potential sideeffects of interferon need to be considered.

The article refers to the fact that the cost of managing one patient with end-stage liver disease is about the same as treating 33 patients with interferon. However, the more relevant question in cost-effectiveness terms is how many patients need to be treated with interferon to prevent one case of end-stage liver disease. This is a more difficult question to answer accurately.

A Hepatitis C Task Force, convened by the National Health and Medical Research Council, is considering the epidemiology and natural history of hepatitis $\mathrm{C}$, and the cost-effectiveness of disease control measures. The task force is due to report to the Australian Health Ministers Advisory Committee by October 1993. 